\title{
Evaluation of Carrot (Daucus carrota) Cultivarss for Growth, Root Yield and Yield Related Traits at Adigrat and Atsbi, Eastern Zone of Tigray Region
}

\author{
Wakuma Biratu Betselot Molla Haile Abebe Haileslassie Gebremeskel \\ Ethiopian Institute of Agricultural Research, Mehoni Agricultural Research Center \\ P.O.Box 2003, Mehoni, Tigray, Ethiopia
}

\begin{abstract}
The experiment was conducted to evaluate the performance of carrot varieties at Adigrat and Atsbi area of Tigray region in 2017 and 2018 cropping season. RCBD was used for the experiment. Data on plant height $(\mathrm{cm})$, leaf number, leaf weight $(\mathrm{gm})$, root length $(\mathrm{cm})$, root diameter $(\mathrm{cm})$ and root yield in terms of ton per hectare were collected and analyzed. Plant height was highly significantly $(p<0.01)$ influenced by carrot cultivars at both locations. Leaf number plant ${ }^{-1}$ was significantly $(p<0.05)$ affected by carrot cultivars only at Atsbi area in 2017. Leaf weight plant ${ }^{-1}$ was significantly influenced by cultivars at Adigrat. In 2017 cropping season, root yield ha ${ }^{-1}$ was non significantly $(\mathrm{p} \geq 0.05)$ affected by cultivars at Adigrat and Atsbi areas. In 2018, plant height, leaf number plant ${ }^{-1}$ and leaf weight plant ${ }^{-1}$ were significantly influenced by carrot cultivars at Adigrat. In 2018, root diameter was significantly affected by cultivars at Adigrat. The maximum plant height $(50.63 \mathrm{~cm})$ was recorded from DzARC-5 and Nantes cultivars in 2017 at Adigrat. The tallest $(46.13 \mathrm{~cm})$ plant height was observed from DzARC-5 varieties in 2017 at Atsbi location. DzARC-5 cultivar showed the maximum leaf weight plant ${ }^{-1}$ at Adigrat and Atsbi areas with leaf weight plant ${ }^{-1}$ of 65.07 and 40.69 respectively since 2017 . In 2018 cropping season, the tallest plant height was recorded from cultivar DzARC-5 $(50.81 \mathrm{~cm})$ at Adigrat. The maximum leaf number plant ${ }^{-1}$ was obtained from DzARC-5 (9.81) at Adigrat location in 2018 production year. In 2018 cropping season, the maximum root yield (30.04ton $\mathrm{ha}^{-1}$ ) was recorded on AUA-108 cultivar at Adigrat. AUA108 cultivar is recommended at Adigrat and Atsbi areas. Further, it is important to reinvestigate the trial at Atsbi as the experiment conducted there for one season alone.
\end{abstract}

Keywords: AUA-108, DzARC-5, DzARC-9, Nantes, Cultivars

DOI: $10.7176 / \mathrm{JNSR} / 10-3-02$

Publication date: February $29^{\text {th }} 2020$

\section{INTRODUCTION}

Carrot (Daucus carota L.) is an important vegetable which is ranked third among the succulent vegetables on the world (Yamaguchi, 1983). It belongs to the family Apiaceae; is a biennial and usually cultivated as an annual crop (De Lannoy, 2001). Carrot is an important source of alpha- and beta-carotene; which are the precursors of vitamin A. It is highly valued as food because it is a rich source of Vitamin A (Zeb and Mahmood, 2004). Vitamin-A malnutrition is among the major public health problems in Ethiopia. Postmus, (1958) report indicated that $9 \%$ of girls and $2.2 \%$ of boys at pre-school and school age had Bitot'sspots, a disease symptom of an eye due to shortage of vitamin-A. Also, prevalence of $1-7.5 \%$ in children under the age of six (Wolde-Gabriel and Demeke, 1985; De Sole et al., 1987; Haile-Meskel, 2011). The prevalence of the disease in Ethiopia was two to 15 -folds of the World Health Organization's cut off point $(0.5 \%)$ for public health significance. Carrot is considered as the major and the cheapest dietary sources of vitamin-A that could mitigate Bitot's spots. Nicolle et al. (2004) reported the presence of $6653 \mathrm{~g}$ carotene in $100 \mathrm{~g}$ of fresh weight of carrots. Furthermore, carrot has abundant nutrients and minerals (Handelman, 2001). It is used as salads, stews and soups with other vegetables. Besides being food, different parts of the crop can be utilized for different medicinal purposes like curing kidney diseases (Anjum and Amjad, 2002).

The exact time of introduction of carrot to Ethiopia is not known; however, the crop has been known since the early 1960s in the research system. Research on carrots in Ethiopia was started at Alemaya College of Agriculture (now Haramaya University) using imported seeds of eight varieties from Kenya in the early 1960s (KifleIyesus, 1994; Kidanemariam, 1969).

However, the production and productivity of this crop is not expanded in different parts of the country. This is attributed to low practical attention of the government to vegetable in general in terms of research system and extension, lack of exhaustive research on carrot and non-consideration of carrot as priority crop. In Tigray region, carrot is very important vegetable crop grown and consumed highly; however, the growers are growing less productive and unimproved varieties. In order to boost the production and productivity of carrot, there was no strategic and exhaustive research done so far rather some adaptation and agronomic trial was conducted in some other part of Ethiopia. However, there are shortage of research on carrot in terms of variety release, adaptation, agronomic and irrigation aspects in virtually all parts of Tigray despite the importance of the crop. So, it is very 
important to support the production of carrot by research in order to improve the productivity and production of carrot. This can be done through evaluation of the performance of carrot varieties to come up with high yielder and adaptable cultivar/s.

So the objective of this research is to evaluate the performance of carrot varieties at Adigrat and Atsbi areas of Eastern zone of Tigray region.

\section{Materials and Methods}

\subsection{Description of the Experimental Site}

The experiment was conducted in 2017 and 2018 cropping year. In, 2017 cropping year, the trial was conducted under rain fed condition in Eastern Tigray zone of Ganta Afashu Woreda (Dibla Seit kebele) and Atsbi Wemberata Woreda of Tigray region. In 2018, the experiment was conducted only at Adigrat.

\subsection{Experimental Procedure}

\subsubsection{Experimental Materials}

Four carrot cultivars namely AUA-108, DzARC-5, DzARC-9 and Nantes were introduced from Debrezeit Agricultural Research Center and evaluated for their performance. In 2017 cropping year, four of them were evaluated at both Adigrat and Atsbi areas under rain fed condition. In 2018, three cultivars were evaluated at Adigrat area; meanwhile of the experiment, the treatments were replicated three times at each locations and in each years.

\subsubsection{Land preparation, Treatment arrangement and Experimental Design}

The land was cleaned, ploughed and leveled in order to create favorable growth condition before planting. The area was partitioned into three homogenous group called bock. Each block has partitioned into plots by considering each treatment must appear in a block equally once. A plot size of $1.5 \mathrm{~m}$ by $1.25 \mathrm{~m}\left(1.875 \mathrm{~m}^{2}\right)$ was used and the distance between blocks and plots was $1 \mathrm{~m}$ and $0.5 \mathrm{~m}$ respectively. The space between rows and plants were $0.25 \mathrm{~m}$ and $0.1 \mathrm{~m}$ respectively. The treatments were arranged in RCBD with three replications. Agronomic practices like, cultivation, weeding and harvesting were done as per the requirement. During the experimental period, NPSB and Urea fertilizer were applied according to the recommendation (100kg NPSB and $100 \mathrm{~kg}$ urea $/ \mathrm{ha}$ ). NPSB was applied during panting; while, urea was applied half at planting time and the remaining half at mid stage of the crop.

\subsection{Data Collected}

All necessary data like plant height $(\mathrm{cm})$, leaf number, leaf weight $(\mathrm{gm})$, root length $(\mathrm{cm})$, root diameter( $\mathrm{cm})$ and root yield ton per hectare were collected.

\subsection{Data Analysis}

The collected data were analyzed using SAS computer software ( 9.3 versions) with general linear model procedure Tewoldebrhan (2009). For parameters showed significance difference, mean separation was done using List Significant Difference (LSD) at 5\% probability level.

\section{Result and Discussion}

\subsection{Plant Height, Leaf number and Leaf Weight per Plant}

In 2017 cropping season, plant height was highly significantly $(p<0.01)$ influenced by carrot cultivars at both locations. Leaf number plant ${ }^{-1}$ was significantly $(p<0.05)$ affected by carrot cultivars only at Atsbi area. To the reverse, except at Atsbi, leaf weight plant ${ }^{-1}$ was highly significantly influenced at Adigrat location (Table 1$)$. In 2018, regardless of their level of significance, plant height, leaf number plant ${ }^{-1}$ and leaf weight plant ${ }^{-1}$ were highly significantly $(p<0.01)$ influenced by cultivar (Table 3$)$. Kassa et al. (2018) reported the existence of significance difference $(P<0.05)$ between carrot cultivars on plant height, leaf number and weight. Also, Poudel et al., (2018) reported radish genotypes showed significant differences on number of leaves per plant.

At Adigrat, the maximum $(50.63 \mathrm{~cm})$ and the minimum plant height $(26.24 \mathrm{~cm})$ was recorded from DzARC-5 and Nantes cultivar in 2017; but DzARC-5 and DzARC-9 was significantly at par with each other. Similarly, the tallest $(46.13 \mathrm{~cm})$ and the shortest plant height $(22.27 \mathrm{~cm})$ was observed from DzARC-5 and Nantes cultivars in 2017 at Atsbi area (Table 1). In this cropping year, leaf number plant ${ }^{-1}$ was not significantly affected by carrot cultivar at Adigrat. The maximum and significantly different leaf number plant ${ }^{-1}$ was recorded on DzARC-9 cultivar at Atsbi with number of leaf plant ${ }^{-1}$ of 13.00 . It also significantly at par with all the

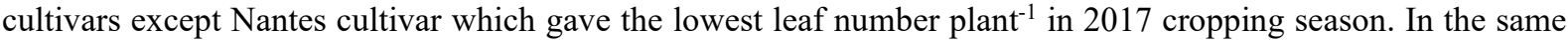
cropping season, DzARC-5 cultivar showed the maximum leaf weight plant ${ }^{-1}$ at Adigrat and Atsbi areas with leaf weight plant ${ }^{-1}$ of $65.07 \mathrm{~g}$ and $40.69 \mathrm{~g}$ respectively. However, this cultivar didn't show statistically significant different from AUA-108 and DzARC-9 at Atsbi area. Similar to leaf number plant ${ }^{-1}$, the lowest leaf weight plant ${ }^{-}$ ${ }^{1}$ was recorded from Nante cultivar at Adigrat and Atsbi area with the average leaf weight value of $15.49 \mathrm{~g}$ and 
$14.58 \mathrm{~g}$ respectively (Table 1 ). This indicate that, the plant growth characters like plant height, leaf number and leaf weight plant ${ }^{-1}$ are varies with cultivar (inherent characters), season and location.

In 2018 cropping season, the highest plant height was recorded from DzARC-5 $(50.81 \mathrm{~cm})$ cultivar; but there was no significance difference between AUA-108 and DzARC-5 on this character. In this cropping season, the maximum leaf number plant ${ }^{-1}$ was obtained from DzARC-5 (9.81) cultivar. Like leaf number plant ${ }^{-1}$, similar response was observed from the investigated cultivars on leaf weight plant ${ }^{-1}$ regardless of the magnitude of the results achieved (Table 3). In line with this, Kassa et al., (2018) reported that there was significance difference $(P<0.05)$ between carrot cultivars on plant growth characters. This might be attributed to inherent characters of the cultivars, environmental condition and variation in adaptability of the cultivars to the area.

\subsection{Root length, Root Diameter and Root Yield}

In 2017 cropping year, root length, root diameter and root yield ton hectare ${ }^{-1}$ were non significantly $(p \geq 0.05)$ affected by carrot cultivars Atsbi areas (Table 2). In both cropping year, root diameter was significantly influenced by carrot cultivars at Adigrat. In 2018 cropping year, root length was non significantly $(p \geq 0.05)$ influenced by carrot cultivars. Root diameter was significantly $(p<0.05)$ influenced by cultivars in 2018 (Table 4). The maximum root diameter $(3.18 \mathrm{~cm})$ was recorded from DzARC-5 cultivar which is statistically at par with (AUA-108=2.89 cm) and (nantes $=2.28$ ) cultivar in 2017 at Adigrat (Table 2). The result indicated that, there is no static performance of carrot cultivars across the location and season (even a cultivar across a location and season). In agreement with this result, Kassa et al., (2018) reported significance variation in root length, total, unmarketable and marketable yields between two cultivars. Root diameter per plant and yield varied significantly among radish cultivar during both seasons (Poudel et al., 2018).

In 2018 cropping season, root length was not significantly ( $\mathrm{p} \geq 0.05)$ influenced by carrot cultivars. In this cropping year, the highest root diameter $(3.05 \mathrm{~cm})$ was recorded on AUA-108 which is statistically similar with DzARC-5 (Table 4). Tabor et al. (2016) reported that DZARC-5 grown at Holeta gave the thickest carrot core diameter; while AUA-108 gave the maximum core diameter at Debre Zeit. This ensures that not only the production season (year), but also, production area (location) affect the performance of carrot cultivars. In terms of root yield ha-1 in 2018 cropping season, the maximum root yield (30.04 ton ha ${ }^{-1}$ ) was recorded on AUA-108 cultivar which is significantly at par with Nantes (24.48); while the lowest root yield (21.54 ton ha-1) was recorded on DzARC-5 cultivar (Table 4). AUA-108 cultivar performs well in both cropping season and location; this might be due to wider adaptability of the cultivar. AUA-108 is adapted to the central highlands of the Ethiopia (Tabor et al., 2016); so, this enable it to produce high yield.

This indicates that the performance of carrot cultivar is the result of the combination of environmental factors (location) and inherent characters of the cultivar. According to Tabor et al. (2016), there is significant variation among carrot cultivars in terms of growth, yield and yield related traits. This author report indicated, Nantes give the highest marketable yield and AUA-108 and DZARC-5 provided good quality yield; Whereas, DZARC-3 and DZARC-9 produced lower yield. Furthermore, Kassa et al. (2018) reported the highly significant root yield and size (diameter and length) obtained from AUA-108 cultivar. AUA-108 carrot cultivar gave the maximum and significantly different total and marketable root yields. Also, Wassu et al. (2014) observed similar result. So, the performance of a cultivar varies with location and even season of production.

Table 1. Mean performance of Carrot cultivars for vegetative growth at different location in 2017

\begin{tabular}{lccccccccc}
\hline \multirow{2}{*}{ Cultivars } & \multicolumn{2}{c}{ Plant height $(\mathrm{cm})$} & \multicolumn{3}{c}{ Leaf Number/ plant } & \multicolumn{3}{c}{ Leaf Weight/plant (gm) } \\
\cline { 2 - 9 } & \multicolumn{2}{c}{ Location } & \multicolumn{2}{c}{ Location } & \multicolumn{3}{c}{ Location } \\
\cline { 2 - 9 } & Adigrat & Atsbi & Mean & Adigrat & Atsbi & Mean & Adigrat & Atsbi & Mean \\
\hline DzARC-9 & $45.16 \mathrm{ab}$ & $40.92 \mathrm{a}$ & 43.04 & 10.74 & $13.00 \mathrm{a}$ & 11.87 & $43.67 \mathrm{~b}$ & $38.80 \mathrm{a}$ & 41.24 \\
AUA-108 & $40.33 \mathrm{~b}$ & $38.63 \mathrm{a}$ & 39.48 & 9.22 & $9.87 \mathrm{ab}$ & 9.55 & $40.82 \mathrm{~b}$ & $22.27 \mathrm{ab}$ & 31.55 \\
DzARC-5 & $50.63 \mathrm{a}$ & $46.13 \mathrm{a}$ & 48.38 & 9.33 & $11.20 \mathrm{ab}$ & 10.27 & $65.07 \mathrm{a}$ & $40.69 \mathrm{a}$ & 52.88 \\
Nantes & $26.24 \mathrm{c}$ & $22.27 \mathrm{c}$ & 24.255 & 7.60 & $7.86 \mathrm{~b}$ & 7.73 & $15.49 \mathrm{c}$ & $14.58 \mathrm{~b}$ & 15.04 \\
\hline LSD & 9.82 & 2.73 & & $\mathrm{~ns}$ & 3.56 & & 17.17 & 23.35 & \\
\hline CV (\%) & 12.10 & 10.46 & & 17.31 & 17.08 & & 20.83 & 40.18 \\
\hline F-test & $* *$ & $* *$ & & & $*$ & & $* *$ & $* *$ \\
\hline
\end{tabular}

$\mathrm{ns}=$ Non-significant at $\mathrm{p} \geq 0.05$, Means within columns for each variable followed by different letters are statistically different at $(p<0.05)$ 
Table 2. Mean performances of Carrot varieties for yield and yield related traits at different location in 2017

\begin{tabular}{|c|c|c|c|c|c|c|c|c|c|}
\hline \multirow{3}{*}{ Cultivars } & \multicolumn{2}{|c|}{ Root Length $(\mathrm{cm})$} & \multicolumn{4}{|c|}{ Root Diameter $(\mathrm{cm})$} & \multicolumn{3}{|c|}{ Root Yield Ton/ha } \\
\hline & \multicolumn{2}{|c|}{ Location } & \multicolumn{4}{|c|}{ Location } & \multicolumn{2}{|c|}{ Location } & \\
\hline & Adigrat & Atsbi & Mean & Adigrat & Atsbi & Mean & Adigrat & Atsbi & Mean \\
\hline DzARC-9 & 16.44 & 17.96 & 17.2 & $2.46 \mathrm{~b}$ & 2.09 & 2.28 & 13.15 & 13.78 & 13.47 \\
\hline AUA-108 & 17.05 & 16.89 & 16.97 & $2.89 \mathrm{ab}$ & 2.26 & 2.28 & 24.15 & 17.41 & 20.78 \\
\hline DzARC-5 & 17.23 & 14.43 & 15.83 & $3.18 \mathrm{a}$ & 2.39 & 2.29 & 26.22 & 14.48 & 20.35 \\
\hline Nantes & 15.70 & 14.50 & 15.1 & $2.28 \mathrm{ab}$ & 1.90 & 2.09 & 20.46 & 13.66 & 17.06 \\
\hline LSD & & & & 0.69 & & & & & \\
\hline $\mathrm{CV}(\%)$ & 6.76 & 13.54 & & 12.78 & 12.21 & & 25.00 & 33.96 & \\
\hline F-test & ns & ns & & $*$ & $\mathrm{~ns}$ & & $\mathrm{~ns}$ & $\mathrm{~ns}$ & \\
\hline
\end{tabular}

ns $=$ Non-significant at $\mathrm{p} \geq 0.05$, Means within columns for each variable followed by different letters are statistically at $(p<0.05)$

Table 3. Mean performance of Carrot varieties for growth traits at Adigrat during 2018

\begin{tabular}{|c|c|c|c|}
\hline Cultivars & Plant height $(\mathrm{cm})$ & Leaf Number/ plant & Leaf Weight/plant (gm) \\
\hline AUA-108 & $43.34^{\mathrm{b}}$ & $8.56^{\mathrm{b}}$ & $28.26^{\mathrm{b}}$ \\
\hline DzARC-5 & $50.81^{\mathrm{a}}$ & $9.81^{\mathrm{a}}$ & $59.86^{\mathrm{a}}$ \\
\hline Nantes & $29.14^{\mathrm{c}}$ & $6.42^{\mathrm{c}}$ & $10.54^{\mathrm{c}}$ \\
\hline $\operatorname{LSD}(5 \%)$ & 6.30 & 1.10 & 9.22 \\
\hline $\mathrm{CV}(\%)$ & 8.85 & 7.72 & 16.20 \\
\hline F-test & $* *$ & $* *$ & $* *$ \\
\hline
\end{tabular}

Means within columns for each variable followed by different letters are statistically different from each other at $(p<0.05)$

Table 4. Mean performances of Carrot varieties for yield and yield related traits at Adigrat Since 2018

\begin{tabular}{lccc}
\hline Cultivars & Root Length $(\mathrm{cm})$ & Root diameter $(\mathrm{cm})$ & Root Yield Ton/ha \\
\hline AUA-108 & 17.21 & $3.05^{\mathrm{a}}$ & $30.04^{\mathrm{a}}$ \\
DzARC-5 & 18.01 & $2.84^{\mathrm{ab}}$ & $21.54^{\mathrm{b}}$ \\
Nantes & 16.96 & $2.43^{\mathrm{b}}$ & $24.48^{\mathrm{ab}}$ \\
\hline LSD $(5 \%)$ & & 0.45 & 8.27 \\
\hline CV $(\%)$ & 7.09 & 9.33 & 18.85 \\
\hline F-test & ns & $*$ & $*$ \\
\hline
\end{tabular}

NS $=$ Non-significant at $\mathrm{p} \geq 0.05$, Means within columns for each variable followed by different letters are statistically different at $(p<0.05)$.

\section{Summary and Conclusions}

A field experiment was conducted for two consecutive years (2017 and 2018) under rain fed condition at Eastern Tigray Zone of Ganta Afashu and Atsbi Wemberta districts to evaluate the performance of carrot varieties. Data on different important characters like plant height $(\mathrm{cm})$, leaf number, leaf weight $(\mathrm{gm})$, root length $(\mathrm{cm})$, root diameter $(\mathrm{cm})$ and root yield ton per hectare were collected and analyzed.

Plant height was highly significantly $(p<0.01)$ influenced by carrot cultivars at both locations. Leaf number plant $^{-1}$ was significantly $(p<0.05)$ affected by carrot cultivars only at Atsbi area in 2017. Leaf number plant ${ }^{-1}$ was not significantly affected by carrot cultivar at Adigrat in 2017 cropping season. In 2018, plant height, leaf number plant ${ }^{-1}$ and leaf weight plant ${ }^{-1}$ were significantly influenced by cultivars at Adigrat. Root diameter was significantly affected by cultivars at Adigrat.

The result showed the maximum plant height $(50.63 \mathrm{~cm})$ was recorded from DzARC-5 and Nantes cultivars in 2017 at Adigrat. The tallest $(46.13 \mathrm{~cm}$ ) plant height was observed from DzARC-5 cultivar in 2017 at Atsbi location. In the same cropping season, the maximum leaf number plant ${ }^{-1}$ (13.00) was recorded on DzARC-9 cultivar at Atsbi. DzARC-5 cultivar showed the maximum leaf weight plant ${ }^{-1}$ at Adigrat and Atsbi areas with leaf weight plant ${ }^{-1}$ of 65.07 and 40.69 respectively. The tallest plant height was recorded from cultivar DzARC-5 $(50.81 \mathrm{~cm})$ at Adigrat in 2018. The maximum leaf number plant ${ }^{-1}$ was obtained from DzARC-5 (9.81) at the study area in 2018 cropping season.

The highest root diameter $(3.05 \mathrm{~cm})$ was recorded from AUA-108 cultivar at Adigrat area. In terms of root yield $\mathrm{ha}^{-1}$ in 2018 cropping season, the maximum root yield (30.04 ton ha $\mathrm{h}^{-1}$ ) was recorded on AUA-108 cultivar at Adigrat. From the result, AUA-108 cultivar is recommended at Adigrat and Atsbi areas. Further, it is important to repeat the experiment at Atsbi as the experiment is done for one season there. 


\section{REFERENCES}

Anjum M. A., Amjad M. 2002. Influence of mother root size and plant spacing on carrot seed production. J. Resour. Sci., 13(2): 105-112.

De Lannoy, G. 2001. Carrot. In: Crop produ- ction in Tropical Africa. R.H. Raemaekers (ed.) Directorate General for International Corporation, Brussels, Belgium. 480- 485.

De Sole, G., Belay, Y., Zegeye, B., 1987. Vitamin-A deficiency in southern Ethiopia.Am. J. Clin. Nutr. 45, 780784.

Haile-Meskel, B., 2011. Experience of World Vision Ethiopia MicronutrientProgram in promoting the production of vitamin-a rich foods. Food Nutr. Bull.22 (4), 366-369.

Handelrman G. J. 2001. The evolving role of carotenoids in human biochemistry. Nutrition, pp. 818-22.

Kassa, M., Zeberhe, T., Abrihaley, S., Michael, T.G., Hagos, K. and Kiros, B.G., 2018. On farm demonstration of improved carrot (Daucuscarota L.) variety in EmbaAlaje district, Northern Ethiopia. International Journal of Agriculture and Biosciences, 7(4), pp.218-221.

Kidanemariam, H. 1969. Vegetable production guide for Eastern Ethiopia. Experiment Station Bulletin No. 62. College of Agriculture, Haile Sellassie I University.

Kifle-Iyesus. 1994. Horticultural development in peasant agriculture. Pp. 29-36. In: Herath E. and Lemma Dessalegne (eds) Horticultural Research.

Nicolle, C., Simon, G., Rock, E., Amouroux, P., Remesy, C., 2004. Genetic variabilityinfluences carotenoid, vitamin, phenolic, and mineral content in white, yellow,purple, orange, and dark-orange carrot cultivars. J. Am. Soc. Hortic. Sci. 129 (4),523-529.

Postmus, S., 1958. Report on Nutritional Needs of Children in Ethiopia. Food andAgriculture Organization, Rome.

Poudel, K., Karki, S., Sah, M.K. and Mandal, J.L., 2018. Evaluation of radish (Raphanus sativus L.) genotypes in Eastern mid-hills condition of Nepal. World News of Natural Sciences, 19, pp.155-159.

Tabor, G., Yesuf, M., Haile, M., Kebede, G. and Tilahun, S., 2016. Performance of some Asian carrot (Daucus carota L. ssp. sativa Hoffm.) cultivars under Ethiopian conditions: Carrot and seed yields. Scientia horticulturae, 207, pp.176-182.

Wassu M, Tewodros B, Nigussie D, Kebede W, Mulatua H, Bekele A, 2015.Registration of "Haramaya I" Carrot (Daucuscarota L.) Variety. East African Journal of Sciences. 8: 65-70.

Wolde-Gabriel, Z., Demeke, T., 1985. Vitamin-A Status in Pre-school Children inEthiopia: An Estimate of National Prevalence. Addis Ababa, Ethiopian NutritionInstitute, September.

Yamaguchi, M. 1983. World Vegetables, Principles Production and Nutritive Values.

Zeb A, Mahmood S. 2004. Carotenoid contents from various sources and their potential health applications. Pakistan J. Nutr., 3(3): 199-204. 